\title{
PENGEMBANGAN PENDIDIKAN AGAMA ISLAM (PAI) PADA KURIKULUM SMP ISLAM TERPADU AL FAHMI PALU
}

\section{DEVELOPMENT OF ISLAMIC RELIGION EDUCATION (PAI) IN CURRICULUM OF ISLAMIC INTEGRATED JUNIOR HIGH SCHOOL AL FAHMI PALU}

\author{
Asnandar Abubakar \\ Balai Penelitian dan Pengembangan Agama Makassar \\ Jl. AP. Pettarani No. 72 Makassar \\ Email: asnandar2.aja@gmail.com
}

Naskah diterima tanggal 12 Februari 2019, Naskah direvisi tanggal 2 April 2019, Naskah disetujui tanggal 30 Mei 2019

\begin{abstract}
Abstrak
Penelitian ini bertujuan untuk mengetahui pengembangan pendidikan agama Islam pada kurikulum sekolah Islam terpadu. Fokus penelitian adalah SMP IT Al Fahmi Palu. Penelitian ini menggunakan pendekatan kualitatif yang bersifat deskriptif eksploratif. Teknik pengumpulan data yang digunakan dalam penelitian ini adalah wawancara, observasi, telaah dokumen. Kurikulum pada SMP IT Al Fahmi Palu Kurikulum SMP IT Al Fahmi Palu, menyesuaikan dengan ciri khas sekolah Islam terpadu yaitu mengintegrasikan nilai-nilai atau ilmu Islam baik yang bersifat Qualiyah maupun Kauniyah dalam suatu kerangka atau bangunan kurikulum. Salah satu tujuannya adalah peserta didik memiliki kepribadian dan akhlak yang baik, memiliki akidah yang bersih, pikiran dan jasmani yang sehat, serta hidup disiplin dan tertib. Pelaksanaan pendidikan agama Islam (PAI) selain bersifat monolitik yang berdiri sendiri juga terintegrasi pada proses pembelajaran baik di dalam maupun di luar kelas. Pengembangan PAI pada kurikulum SMP IT Al Fahmi dapat dilihat dari penambahan jam pelajaran pada mata pelajaran pendidikan agama Islam, Al-Quran, dan bahasa Arab, integrasi nilai-nilai Islam pada mata pelajaran umum dan pelajaran ekstrakurikuler seperti memanah, renang, dan silat, dibuka kelas tahfidz bagi peserta didik yang memiliki bakat untuk meningkatkan hafalan Al-Quran, adanya kegiatan Quran camp, serta sanksi hafalan beberapa ayat Al-Quran bagi peserta didik yang melanggar tata tertib sekolah.
\end{abstract}

Kata Kunci: sekolah Islam terpadu, kurikulum, pendidikan agama Islam

\begin{abstract}
This study aims to determine the development of Islamic religious education in an integrated Islamic school curriculum. The research locus is Al Fahmi Palu Middle School. This study uses a descriptive explorative qualitative approach. Data collection techniques used in this study were interviews, observation, document review. The curriculum at junior high school IT Al Fahmi Palu adapts to the characteristics of integrated Islamic schools, namely integrating Islamic values both Qualiyah and Kauniyah in a framework or curriculum building. One of the goals is that students have good personality and character, have a clean, mind and body that is healthy, and live in discipline and order. The implementation of Islamic religious education (PAI) in addition to being stand-alone monolithic is also integrated in the learning process both inside and outside the classroom. The development of PAI in junior high school IT Al Fahmi curriculum can be seen from the addition of lesson hours to subjects in Islamic education, the Qur'an, and Arabic, integration of Islamic values in general subjects and extracurricular subjects such as archery, swimming, and martial arts, the tahfidz class was opened for students who had the talent to improve memorization of the Qur'an, the existence of Qur'an camp activities, as well as sanctions for memorizing several verses of the Qur'an for students who violated school rules.
\end{abstract}

Keywords: integrated Islamic school, curriculum, Islamic religious education 


\section{PENDAHULUAN}

$\mathrm{P}$ erkembangan dunia pendidikan dewasa ini begitu pesat, baik dalam aspek kualitas dan kuantitas lembaga pendidikan, maupun dalam aspek proses penyelenggaraan pendidikan termasuk di dalamnya sistem pembelajaran, metode, strategi, maupun teoriteori belajar mengajar. Implikasi perkembangan ini tentu mendapat banyak pembaharuan untuk menemukan formula layanan pendidikan sesuai agama, norma, budaya, dan nilai-nilai hidup tanpa mengesampingkan perkembangan ilmu pengetahuan dan teknologi.

Perhatian pemerintah terhadap peningkatan kualitas pendidikan terus dilakukan baik dalam bentuk regulasi maupun pengembangan karakteristik lembaga pendidikan. Sekolah umum dan madrasah terus dielaborasi kurikulumnya agar dapat menghasilkan generasi yang memiliki pengetahuan yang tinggi, memiliki sikap yang santun, berkepribadian serta berakhlak mulia. Salah satu upaya pemerintah adalah pelaksanaan dan penerapan kurikulum 2013 yang di dalamnya terdapat penambahan jam pelajaran agama. Pemerintah berharap peserta didik memiliki intelektualitas yang dilandasi nilainilai agama.

Dikotomi pelaksanaan pendidikan umum dan agama oleh lembaga pendidikan terus dikikis, tujuannya adalah mengembangkan lembaga pendidikan yang memadukan pendidikan agama dan pendidikan umum, agar dapat membentuk generasi bangsa yang memiliki mental dan akhlak yang kuat seiring dengan gencarnya globalisasi informasi tanpa filter kesesuaian budaya yang dapat mempengaruhi karakter dan nilai-nilai sosial bangsa kita.

Salah satu lembaga pendidikan yang memadukan pendidikan agama dan umum adalah lembaga pendidikan Islam terpadu atau sekolah Islam terpadu. Sistem pembelajaran pendidikan ini adalah mengintegrasikan nilainilai agama dalam ranah kognitif, afektif, dan psikomotorik peserta didik, menggali potensi dan kreativitas peserta didik baik bakat dalam bidang seni maupun olahraga, dan membuka wawasan dan nalar berpikir secara maksimal.
Geliat Sekolah Islam terpadu mulai kelihatan di tahun 1990-an, dan sejak itu berkembang dan terus meningkat. Begitu pesatnya, lembaga pendidikan ini membentuk suatu wadah atau lembaga perkumpulan yang salah satunya adalah jaringan sekolah Islam terpadu. Seiring dengan banyaknya bermunculan sekolah Islam berbasis terpadu, seiring itu pula kepercayaan dan minat masyarakat untuk menyentuh lembaga pendidikan tersebut terus meningkat. Keberhasilan sekolah Islam terpadu menarik kepercayaan masyarakat terlihat dari aspek kualitas pengelolaan, mulai dari sistem pengajaran dan pembelajaran yang baik, sampai pada aspek sarana dan prasarana yang memadai. Sistem pembelajaran yang baik mampu memaksimalkan strategi dan metode pembelajaran sehingga peserta didik dapat belajar secara efisien, efektif dan menyenangkan yang pada akhirnya dapat mencapai tujuan pembelajaran secara optimal.

Sistem pembelajaran yang memadukan nilai-nilai agama atau nilai-nilai Islami pada mata pelajaran umum atau kegiatan sekolah lainnya, memberikan kepercayaan kepada masyarakat untuk menyekolahkan anak pada sekolah Islam terpadu, agar anak mendapatkan pendidikan moral dan akhlak melalui pendidikan agama, selain pendidikan umum yang berkualitas. Hal ini juga dapat menekan kekhawatiran orang tua terhadap minimnya komposisi pendidikan agama pada sekolah umum lainnya. Sistem pembelajaran inilah salah satunya yang akan dilihat dan dicermati, sehingga perlu diadakan penelitian terkait hal tersebut.

Pada aspek pengembangan kurikulum, sekolah Islam terpadu memberikan porsi yang lebih pada pembelajaran tambahan yang berhubungan dengan pendidikan agama seperti hafalan beberapa juz dalam Alquran dan perkembangan ilmu pengetahuan dan teknologi seperti pembelajaran bahasa Inggris dan komputer, serta pembelajaran yang disesuaikan dengan bakat dan minat peserta didik. Hal ini diharapkan kompetensi lulusan peserta dapat bersaing dan unggul dengan lulusan sekolah umum lainnya. Tetapi meskipun begitu, intensitas jam belajar sekolah Islam terpadu 
yang melebihi standar jam pelajaran sekolah umum lainnya (biasanya dari jam 07.30 pagi sampai jam 15.00 sore) belum tentu menjamin dapat memberikan pembelajaran yang efektif dan efisien. J. Drost dalam Darmin (2006: 19) memberikan perbandingan jam pelajaran pada SLTP di Jerman 32 jam, di Belanda dan Australia 35 jam sedangkan di Indonesia umumnya melebihi jam pelajaran tersebut, belum menunjukkan gejala yang menggembirakan karena adanya faktor non kurikulum yang dominan mempengaruhi mutu prestasi belajar anak didik.

Hasil penelitian Soemanto (2014) tentang pendidikan agama Islam Terpadu pada SMPIT Bina Umat Yogyakarta menyimpulkan bahwa minat masyarakat terhadap sekolah Islam terpadu terus meningkat, di antara alasannya adalah adanya pengintegrasian pendidikan agama dan pendidikan umum, secara tidak langsung membimbing moral dan akhlak siswanya, dan adanya pemberian keterampilan kepada siswa yang tidak ditawarkan pada sekolah umum.

Begitu pun pada hasil penelitian yang dilakukan oleh Suprapto (Edukasi, 2014) tentang model pembelajaran pendidikan agama Islam Terpadu di SMA-IT Darul Hikam Bandung, menyebutkan bahwa pembelajaran pada sekolah Islam terpadu mengintegrasikan nilai-nilai ajaran Islam ke dalam struktur kurikulum yang memadukan antara pemahaman dan implementasi dengan pendekatan pembelajaran yang aktif, inovatif, kreatif, efektif, dan menyenangkan.

Penelitian lainnya terkait sekolah Islam terpadu yang pernah dilakukan di antaranya adalah; (a) Sekolah Islam Terpadu Dalam Peta Sistem Pendidikan Nasional, oleh Suyatno (Prodi PGSD Universitas Ahmad Dahlan Yogyakarta), hasil penelitiannya menunjukkan bahwa sekolah Islam terpadu memang sudah terintegrasi dalam sistem pendidikan nasional. (b) Manajemen Pendidikan Islam Terpadu Dalam Membentuk Siswa Berakhlak Mulia (Studi Kasus di SDIT Muhammadiyah AlKautsar Gumpang Kartasura Sukoharjo Tahun 2012-2013), oleh Budi Hadi (2013), hasil penelitiannya menunjukkan bahwa perumusan visi misi, kurikulum terpadu, pembelajaran terpadu, guru yang berkualitas, pendekatan terpadu dan budaya sekolah, telah mampu membentuk siswa berakhlak mulia (berkarakter), dan telah dijalankan sesuai fungsi manajemen (planning, organizing, actuating, controlling, evaluation). (c) Implementasi Konsep Pendidikan Islam Terpadu Di SMP Islam Terpadu PAPB Pedurungan Semarang, oleh Euis Sumaiyah (2010), hasil penelitiannya menunjukkan bahwa 1) pendidikan islam terpadu merupakan model pendidikan yang utuh menyeluruh, integral, bukan parsial, syumuliyah bukan juz'iyah. 2) Implementasi pendidikan Islam terpadu, pendidikan ini memadukan tiga aspek kurikulum yaitu: Kurikulum Diknas, Kurikulum pendidikan Islam (muatan lokal berbasis Islam), dan pengembangan diri.

Dari beberapa hasil penelitian tersebut di atas memberikan gambaran tentang kekhasan dari sekolah Islam terpadu baik pada aspek kurikulum maupun sistem pembelajaran. Dan juga memberikan gambaran tentang meningkatnya minat masyarakat terhadap konsep dari sekolah Islam terpadu. Tetapi meskipun penelitian tentang sekolah Islam terpadu telah banyak dilakukan, tapi pada aspek pengelolaan dan sistem pembelajaran masih perlu ditelusuri. Sehingga setidaknya memberikan gambaran kepada kita alternatif konsep pengelolaan sekolah yang sesuai dengan kebutuhan dan keinginan masyarakat, dan sekiranya kalau memang dianggap cocok atau sesuai dengan kultur pendidikan yang dewasa ini, mengapa pemerintah tidak mengembangkan sistem atau konsep sekolah Islam terpadu pada sekolah-sekolah umum yang ada saat ini.

Begitu pun jika dilihat dari kekhasan sekolah Islam terpadu, sangat penting untuk ditelusuri dalam memberikan gambaran kepada masyarakat dan pemerintah sebagai alternatif pilihan pendidikan. Kekhasan tersebut dapat dilihat dari konsep atau pembelajaran unggulan seperti pengembangan kurikulum berbasis teknologi atau berbasis tahfiz, ataupun kurikulum yang berbasis potensi daerah atau budaya dan nilai-nilai lokal daerah.

Olehnya itu, penelitian pendidikan Islam terpadu perlu dilakukan untuk melihat bagaimana gambaran pengembangan pendidikan agama Islam pada kurikulum sekolah 
Islam terpadu dan faktor pendukung dan penghambatnya?. Penelitian ini diharapkan dapat berguna sebagai data pendukung bagi pengambil kebijakan dalam hal ini kementerian agama dan kementerian pendidikan nasional terkait dengan peningkatan mutu sekolah. Hasil penelitian ini dapat dijadikan perbandingan dan pengembangan konsep pengelolaan sekolah, utamanya penerapan pendidikan agama Islam, serta dapat menjadi pendukung dalam merumuskan strategi dan tahapan-tahapan dalam menyusun kurikulum sesuai dengan kebutuhan dan keinginan masyarakat akan pendidikan moral dan akhlak yang dilandasi nilai-nilai agama.

\section{Tinjauan Pustaka \\ Pendidikan Agama Islam dan Kurikulum}

Pada Peraturan Pemerintah Republik Indonesia Nomor 55 Tahun 2007 tentang Pendidikan Agama dan Pendidikan Keagamaan pasal 1 ayat 1 menyebutkan bahwa pendidikan agama adalah pendidikan yang memberikan pengetahuan dan membentuk sikap, kepribadian, dan keterampilan peserta didik dalam mengamalkan ajaran agamanya, yang dilaksanakan sekurang-kurangnya melalui mata pelajaran/kuliah pada semua jalur, jenjang, dan jenis pendidikan. Pada pasal 2 ayat 1 dan 2 disebutkan fungsi dan tujuan pendidikan agama, yaitu; pendidikan agama berfungsi membentuk manusia Indonesia yang beriman dan bertakwa kepada Tuhan Yang Maha Esa serta berakhlak mulia dan mampu menjaga kedamaian dan kerukunan hubungan intern dan antar umat beragama. Pendidikan agama bertujuan untuk berkembangnya kemampuan peserta didik dalam memahami, menghayati, dan mengamalkan nilai-nilai agama yang menyerasikan penguasaannya dalam ilmu pengetahuan, teknologi dan seni.

Ibnu Qayyim Al Jauziyah dalam Iqbal (2015:472) mengemukakan bahwa tujuan pendidikan Islam yang utama adalah menjaga kesucian (Fitrah) manusia dan melindunginya agar tidak jatuh ke dalam penyimpangan serta mewujudkan dalam dirinya penghambaan (ubudiyah) kepada Allah Swt.

Gunawan (2012:202) mengemukakan bahwa pendidikan agama Islam di sekolah diharapkan mampu membentuk kesalehan pribadi (individu) dan kesalehan sosial sehingga dapat menekan sikap fanatisme, sikap intoleran yang dapat memperlemah kerukunan hidup umat beragama dan memperlemah persatuan dan kesatuan nasional. Pendidikan agama Islam diharapkan mampu menciptakan ukhuwah Islamiyah yang dalam arti yang luas adalah ukhuwah fi al-ubudiyah, ukhuwah fi alinsaniyah, ukhuwah fi al-wathaniyah wa alnasab, dan ukhuwah fi din al-Islam.

Dari beberapa pendapat yang dikemukakan, dapat dirumuskan bahwa pendidikan agama Islam adalah pendidikan yang memberikan pengetahuan dan membentuk sikap, kepribadian, dan keterampilan peserta didik dalam memahami, menghayati, dan mengamalkan nilai-nilai agama Islam, sehingga dapat menjaga ketakwaan dan kemuliaan sebagai hamba di hadapan Allah Swt.

Omar Muhammad at-Taumy alSyaibani dalam Gunawan (2012:33) menyebutkan bahwa prinsip-prinsip yang harus menjadi acuan dalam penyusunan kurikulum pendidikan Islam adalah; (1) berorientasi pada Islam, termasuk ajaran dan nilai-nilainya, (2) prinsip menyeluruh pada tujuan-tujuan dan kandungan kurikulum, (3) prinsip keseimbangan yang relatif antara tujuan-tujuan dan kandungan kurikulum, (4) prinsip interaksi antara kebutuhan peserta didik dan kebutuhan masyarakat, (5) prinsip pemeliharaan perbedaan individual di antara peserta didik, baik perbedaan dari segi minat, bakat, kemampuan, kebutuhan dan lainnya, (6) prinsip perkembangan dan perubahan sesuai dengan tuntutan yang ada dengan tidak mengabaikan nilai-nilai absolut, dan (7) prinsip perpatutan (integritas) antara mata pelajaran, pengalamanpengalaman, dan aktivitas yang terkandung dalam kurikulum, begitu pula dengan peraturan antara kandungan kurikulum dengan kebutuhan peserta didik dan kebutuhan masyarakat.

\section{Pengertian Sekolah Islam Terpadu}

Pembelajaran terpadu merupakan suatu pendekatan yang berorientasi pada praktik pembelajaran yang disesuaikan dengan kebutuhan perkembangan anak. Pelaksanaan pendekatan pembelajaran terpadu bertolak dari 
suatu topik atau tema yang dipilih dan dikembangkan oleh guru bersama-sama dengan anak. Tujuan dari tema ini untuk menguasai konsep-konsep dari mata pelajaran terkait dijadikan sebagai wahana untuk mempelajari dan menjelajahi topik atau tema tersebut. (Suprapto, 2014:19).

Sekolah Islam Terpadu (SIT) adalah sekolah yang diselenggarakan dengan memadukan ajaran dan nilai-nilai luhur agama Islam secara integratif dalam struktur kurikulum dengan menggunakan pendekatan pembelajaran efektif dan efisien, yang mengedepankan keseimbangan pencapaian aspek kognitif, afektif, dan psikomotorik melalui pelibatan yang optimal dan kooperatif (koordinatif, konsultatif, sinkronisasi) antara sekolah (terutama Guru), keluarga (orang tua), dan masyarakat dalam membangun karakter dan kompetensi yang harus dimiliki oleh peserta didik. (Suprapto, 2014:30).

Dalam buku Standar Mutu Jaringan Sekolah Islam Terpadu (JSIT) Indonesia (2014) dijelaskan bahwa sekolah Islam Terpadu (SIT) adalah sekolah yang mengimplementasikan konsep pendidikan Islam berlandaskan Alquran dan As Sunnah. Konsep operasional SIT merupakan akumulasi dari proses pembudayaan, pewarisan, dan pengembangan ajaran agama Islam, budaya dan peradaban agama Islam dari generasi ke generasi. Istilah terpadu dalam SIT dimaksudkan sebagai penguat (taukid) dari Islam itu sendiri. Maksudnya adalah Islam yang utuh, menyeluruh, integral, bukan parsial, syumuliah bukan juz'iyah. Dalam aplikasinya SIT diartikan sebagai sekolah yang menerapkan pendekatan penyelenggaraan dengan memadukan pendidikan umum dan pendidikan agama menjadi satu jalinan kurikulum. Dengan pendekatan ini semua mata pelajaran dan semua kegiatan sekolah tidak lepas dari bingkai ajaran dan pesan nilai Islam.

Dari beberapa pengertian di atas, dapat dijabarkan pengertian sekolah Islam terpadu adalah sekolah yang pelajarannya memadukan pelajaran umum dan pelajaran pengembangan bakat dan minat peserta didik dengan pelajaran agama Islam. Pelajaran Islam tersebut, selain dilakukan dengan mengintegrasikan ke dalam pelajaran umum juga dilakukan secara monolitik (tersendiri) pada mata pelajaran agama yang berlandaskan Alquran dan As Sunnah yang dilaksanakan secara efektif dan efisien dengan memperhatikan aspek kognitif, afektif, dan psikomotorik, serta melibatkan orang tua dan masyarakat.

Prinsip Penyelenggaraan Sekolah Islam Terpadu berdasarkan Buku Standar JSIT Indonesia (2014:6-7) adalah sebagai berikut: (1) menyakini bahwa pendidikan Islam merupakan aktivitas dakwah yang merupakan pekerjaan mulia dan menuntut dedikasi, loyalitas, dan kerja keras. (2) pendidikan dilaksanakan dengan tulus ikhlas, dedikasi yang tinggi dan cara-cara yang bijak dan dipandang sebagai kewajiban menjalankan perintah Allah Swt. mengajak, menuntun manusia menuju ke jalan Allah (QS, 16:125). Menjalankan aktivitas pendidik merupakan amanah yang diterima dari orang tua siswa, dan menunaikan amanah merupakan perintah Allah Swt. yang harus ditunaikan dengan baik, profesional, dan penuh tanggung jawab (QS, An Nisa: 58) (3) pendidikan hakikatnya adalah mengajarkan seluruh kandungan Islam (Alquran dan Hadits) sebagai satu kesatuan 'Ilmu Allah'. Oleh Karenanya seluruh kandungan kurikulum di SIT dikembangkan berdasarkan keyakinan dan pandangan yang terpadu bersendikan ketauhidan Allah Swt. SIT berupaya mengintegrasikan Ilmu Allah yang tersurat dalam Alquran dan Hadits ('Ulumul Qauliyah) dengan nilai kauniyah dan qauliyah dalam bangunan kurikulum.

\section{Tujuan Pendidikan Sekolah Islam Terpadu}

Tujuan Pendidikan SIT adalah membentuk karakter utama kepada seluruh peserta didik, yaitu; Salimul Aqidah, meyakini Allah Swt. sebagai pencipta, pemilik, pemelihara, dan penguasa alam semesta dan menjauhkan diri dari segala pikiran, sikap, dan perilaku, bi'dah, khurafat, dan syirik; Sohihul Ibadah, terbiasa dan gemar melaksanakan ibadah yang meliputi; sholat, shaum, tilawah Alquran, dzikir, dan doa sesuai petunjuk Alquran dan AsSunnah; Matinul Khuluq, Menampilkan perilaku yang santun, tertib, disiplin, sabar, gigih, dan pemberani dalam menghadapi permasalahan hidup sehari-hari; Qodirun 'alal Kasbi, mandiri dalam memenuhi 
keperluan hidupnya dan memiliki bekal yang cukup dalam pengetahuan, kecakapan, dan keterampilan dalam usaha memenuhi kebutuhan nafkahnya.

Tujuan berikutnya adalah; Mutsaqoful Fikri, memiliki kemampuan berpikir yang kritis, logis, sistematis, dan kreatif yang menjadikan dirinya berpengetahuan luas dan menguasai kompetensi akademik dengan sebaik-baiknya dan cermat serta cerdik dalam mengatasi segala problem yang dihadapi; Qowiyul jismi, memiliki badan dan jiwa yang sehat dan bugar, stamina dan daya tahan tubuh yang kuat, serta keterampilan beladiri yang berguna untuk dirinya dan orang lain; Mujahadah li nafsihi, memiliki kesungguhan dan motivasi yang tinggi dalam mengejar prestasi sekolah; Munazhom $f i$ Syu'nihi, tertib dalam menata segala pekerjaan, tugas dan kewajiban; berani dalam mengambil resiko namun tetap cermat dan penuh perhitungan dalam melangkah; Harisun 'alal waqti, selalu memanfaatkan dan mengatur waktu dengan kegiatan yang bermanfaat; Nafi'un li Ghohiri, peduli kepada sesama dan lingkungan serta memiliki kepekaan untuk membantu orang lain (Buku Standar Mutu JSIT Indonesia 2014:78).

\section{METODE PENELITIAN}

Penelitian ini menggunakan pendekatan kualitatif yang bersifat deskriftif eksploratif. Pendekatan ini digunakan untuk melihat realitas pengelolaan sekolah Islam Terpadu termasuk di dalamnya sistem pembelajaran pendidikan agama Islam dan kurikulum.

Sasaran dan lokasi penelitian ini adalah sekolah Islam terpadu dengan jenjang satuan pendidikan sekolah menengah pertama. Sekolah Islam terpadu yang dimaksud adalah sekolah menengah pertama Islam terpadu (SMP IT) Al Fahmi Kota Palu Sulawesi Tengah.

Teknik pengumpulan data menggunakan wawancara, observasi, telaah dokumen. Wawancara dilakukan untuk menghimpun data terkait dengan pengintegrasian nilai-nilai Islam pada mata pelajaran, pelaksanaan pembelajaran, dan faktor-faktor penghambat pengelolaan sekolah Islam terpadu.
Pengamatan dilakukan untuk menghimpun data terkait dengan pelaksanaan pembelajaran, lingkungan sekolah, sarana dan prasarana sekolah. Telaah dokumen dilakukan untuk menghimpun data terkait dengan sejarah singkat sekolah atau profil sekolah, konsep kurikulum, dan bahan ajar yang digunakan.

Analisis data dalam penelitian ini melalui dua tahapan, yaitu pertama ketika di lapangan berupaya mempersempit fokus kajian dalam rangka membatasi data yang dikumpulkan. Data yang terkumpul kemudian dideskripsi dan diklasifikasikan sesuai dengan bagian-bagian yang telah ditentukan. Dan kedua, dianalisis dengan mengeksplorasi data primer yang didukung data sekunder dan kemudian dikuatkan dengan perspektif teori berdasarkan pustaka yang ada.

\section{PEMBAHASAN}

\section{Setting Penelitian}

Kota Palu merupakan ibu kota Provinsi Sulawesi Tengah, terbagi dalam delapan Kecamatan, yaitu Kecamatan Palu Barat, Tatanga, Ulujadi, Palu Selatan, Palu Timur, Mantikulore, Palu Utara, dan Tawaeli, serta terdapat 45 kelurahan.

Kota Palu memiliki luas wilayah 395,06 kilometer persegi dengan jumlah penduduk mencapai 362.202 jiwa (tahun 2014), sehingga tingkat kepadatan penduduk Kota Palu sebesar $916 \mathrm{jiwa} / \mathrm{km}^{2}$. Pada penyebaran penduduk tingkat kecamatan, ternyata Kecamatan Palu Timur merupakan wilayah dengan kepadatan penduduk tertinggi yaitu $8.889 \mathrm{jiwa} / \mathrm{km}^{2}$.

Pada sektor pendidikan, sebagian penduduk Kota Palu tergolong penduduk usia muda, sehingga umumnya berada pada usia sekolah. Pada Tahun 2014 jumlah Taman Kanak-kanak (TK) dan Raudatul Anfal sebanyak 122 unit dengan murid sebanyak 3.883 orang. Untuk tingkat Sekolah Dasar (SD) terdapat 162 unit pada tahun 2014, yang terdiri dari 132 unit sekolah dasar negeri dan 30 sekolah dasar swasta. Jumlah sekolah dasar terbanyak terdapat di Kecamatan Palu Timur sebanyak 28 unit dengan jumlah murid sebanyak 7.215 orang. Sedangkan jumlah Madrasah Ibtidaiah (MI) di Kota Palu pada tahun 2014 sebanyak 20 unit 
yang terdiri dari 2 unit Madrasah Ibtidaiah Negeri dan 18 unit Madrasah Ibtidaiah Swasta.

Pada jenjang Sekolah Menengah Pertama (SMP) terdapat 45 unit sekolah dengan 16.322 murid dan 1.103 guru, dengan rasio antara murid terhadap guru sebesar 15. Sementara itu, jumlah Madrasah Tsanawiyah (MTS) sebanyak 25 unit yang terdiri 4 MTS negeri dan 21 MTS swasta. Pada tahun 2014, tampak peranan swasta pada jenjang pendidikan SMA sangat besar yang ditunjukkan oleh jumlah sekolah swasta sebanyak 25 unit dengan daya tampung murid sebanyak 10.161 siswa dan jumlah guru sebanyak 885 orang. Sedangkan jumlah Madrasah Aliyah (MA) di Kota Palu sebanyak 9 unit yang terdiri dari 2 MA Negeri dan 7 MA swasta dengan daya tampung murid berjumlah 1.945 murid dan 237 guru. Hal yang sama juga terjadi pada SMK, hampir 67 persen dari total SMK yang ada adalah SMK swasta. Pada Tahun 2014 jumlah murid SMK sebanyak 8.862 orang.

SMP IT Al Fahmi Sendiri berada di Jl. Gelatik No. 88 Kota Palu, dekat dengan pusat perkantoran dan jalur menuju bandar udara Kota Palu. Sekolah ini terletak di wilayah perumahan sehingga tempatnya tidak terlalu terganggu oleh kebisingan kendaraan bermotor ataupun pabrikpabrik. Gedung sekolah SMP IT masih berada dalam satu lokasi yang sama dengan SD IT, di dalam lokasi tersebut selain gedung ruang kelas belajar, juga terdapat mesjid yang digunakan secara bersama-sama, gedung olahraga dan kesenian, dan kantor yayasan Al Fahmi.

\section{Manajemen Pimpinan SMP IT AL Fahmi}

Pengelolaan sekolah yang dilakukan oleh kepala SMP IT Al Fahmi (Ibu Roslini Hudu) setidaknya mengikuti prinsip-prinsip manajemen, yaitu dengan melakukan perencanaan program, pengendalian, penggerakan, sampai kepada tahap evaluasi. Pengelolaan ini tentunya melibatkan guru-guru dan melalui pertimbangan yayasan.

Visi Sekolah adalah Generasi cerdas, berakhlak qurani, unggul dibidang ilmu pengetahuan dan teknologi. Misi Sekolah adalah menumbuh kembangkan minat belajar yang tinggi agar berwawasan luas dan berilmu pengetahuan yang seimbang antara pengetahuan umum dan agama, membentuk pribadi santri yang mampu baca tulis Alquran dengan baik serta berakhlak karimah serta menjadi contoh teladan di tengah keluarga, teman dan masyarakat, membentuk santri yang memiliki prestasi akademik dan non akademik yang berorientasi pada kecakapan hidup serta memiliki daya saing akademik untuk memasuki lembaga pendidikan yang terbaik.

Tahap awal pelaksanaan pendidikan di Sekolah Menengah Pertama Islam Terpadu (SMP IT) Al Fahmi adalah dengan merumuskan visi dan misi sekolah. Perumusan visi dan misi ini dilakukan oleh kepala sekolah (Ibu Roslini Hudu) bersama-sama dengan pengurus yayasan Al Fahmi dan beberapa orang guru. Perumusan visi misi ini mengacu pada semangat Jaringan Sekolah Islam Terpadu (JSIT) yang berusaha mewujudkan sekolah yang secara efektif mengembangkan proses pendidikan yang dapat menumbuhkembangkan potensi fitrah anak didik menuju visi pembentukan generasi yang takwa dan berkarakter pemimpin.

Setelah perumusan visi misi ini maka ditetapkanlah program sekolah selama satu tahun berjalan. Program sekolah ini mengacu pada visi dan misi sekolah. Program sekolah ditetapkan oleh kepala sekolah bersama-sama dengan guru. Strategi program sekolah ini dibuat per bulan, per semester dan per tahun. Program per bulan adalah pelaksanaan pembelajaran yang memuat jadwal mengajar guru, kegiatankegiatan yang berhubungan dengan hari-hari besar Islam dan nasional, kegiatan ekstrakurikuler, dan evaluasi pembelajaran. Program per semester adalah pelaksanaan pembelajaran yang memuat program bulanan juga memuat jadwal belajar selama satu semester dan evaluasi bagi siswa atau ujian semester, serta ditambah kegiatan-kegiatan wisuda Quran dan English Camp. Program tahunan adalah berisi program bulanan, program semester, dan juga ditambah dengan program persiapan dan pelaksanaan ujian nasional (UN), pengumuman dan pendaftaran ulang penerimaan siswa baru.

Penerimaan siswa baru pada SMP IT Al Fahmi dilakukan dengan membuka pendaftaran terlebih dahulu kemudian melakukan ujian kompetensi. Ujian kompetensi yang diberikan 
kepada calon siswa baru adalah pelajaran matematika, bahasa Inggris, dan pengetahuan umum. Setelah proses penerimaan, selanjutnya sekolah mengadakan matrikulasi bagi siswa baru untuk pelajaran bahasa Arab, Alquran, ilmu pengetahuan alam, dan sains. Matrikulasi ini bertujuan untuk menyelaraskan pengetahuan dan sikap para siswa baru terhadap pelajaranpelajaran yang menjadi substansi utama pembelajaran di SMP IT Al Fahmi.

Dalam menjalankan program sekolah, kepala sekolah menjalankan langkah-langkah strategis diantaranya adalah membuat regulasiregulasi terkait peningkatan program pembelajaran dan membuat proposal-proposal dalam rangka peningkatan sarana dan prasarana sekolah. Proposal pengembangan madrasah ini biasanya diajukan pada instansi pemerintah yang terkait yaitu kementerian pendidikan dasar dan menengah. Regulasi-regulasi yang dibuat adalah yang berhubungan dengan peningkatan kompetensi dan disiplin peserta didik misalnya tata tertib sekolah.

Sekolah Menengah Pertama Islam Terpadu (SMP IT) Al Fahmi dikelola oleh kepala sekolah Ibu Roslini Hudu dibantu oleh seorang wakil kepala yaitu bapak Abd. Ghofur dan dua orang tenaga kependidikan yang mengurusi ketatausahaan atau administrasi sekolah. Proses pembelajaran diserahkan kepada guru-guru yang terdiri dua orang guru PNS dan 11 orang guru yayasan.

Dalam pengelolaan pendidikan di sekolah, kepala sekolah bertanggungjawab langsung kepada pihak yayasan. Unsur pertanggungjawaban kepala sekolah kepada yayasan terkait dengan pelaksanaan program sekolah yang di dalamnya memuat penerimaan siswa baru, pelaksanaan dan hasil ujian nasional, dan penggunaan anggaran pendidikan selama satu tahun berjalan.

Pada penggerakan sekolah atau pelaksanaan proses pendidikan, kepala sekolah mengacu kepada petunjuk pengelolaan sekolah Islam terpadu yang dikeluarkan oleh JSIT yang didalamnya juga sudah memuat tentang peningkatan mutu. Tetapi meski sudah ada petunjuk dari JSIT, kepala sekolah tetap membuat strategi dalam pengelolaan sekolah yaitu dengan mengajak peran serta guru. Guru selain memberikan pengajaran di dalam kelas juga mendapat tugas kependidikan di luar kelas, yaitu seperti pengawasan dan pengendalian tata tertib sekolah dipercayakan kepada wakil kepala sekolah, memberikan kewenangan dan tanggung jawab kepada beberapa guru untuk menangani kegiatan ekstrakurikuler seperti english club, kelas Olimpiade, kegiatan memanah, berenang, dan silat. Kepala sekolah juga membentuk tim sukses ujian nasional (UN) yang tanggung jawabnya diserahkan kepada beberapa orang guru.

Pengendalian sekolah dilakukan oleh kepala sekolah dengan mengontrol programprogram sekolah apakah sudah berjalan sesuai dengan tahap-tahapan yang telah disetujui. Di antaranya adalah memberikan penilaian terhadap efektivitas tata tertib, efektivitas proses belajar mengajar (capain pembelajaran), mengawasi pelaksanaan ujian sekolah dan ujian nasional, mengawasi pelaksanaan penerimaan siswa baru.

\section{Pengembangan PAI pada Kurikulum SMP IT Al Fahmi}

Kurikulum merupakan salah satu bagian yang sangat strategis pada komponen pendidikan dan memiliki kontribusi yang besar dalam proses transformasi keilmuan pada spektrum pendidikan yang begitu luas. Abdurrahman AnNahlawi mengemukakan bahwa karakteristik kurikulum integratif merupakan bentuk kurikulum yang saling bertalian dan terkoordinasi antara bagian-bagiannya dan materi- materi pelajarannya. Seluruh materi pelajaran dan pengetahuan yang akan diberikan kepada para siswa harus bertalian dengan poros (core) tertentu (Aziz, 2018) .

Standar kurikulum yang dikembangkan oleh SMP IT Al Fahmi mempunyai kekhasan tersendiri dan mempunyai kompetensi yang diperluas dari kurikulum nasional, termasuk pendidikan agama Islam yang tetap mengacu pada standar nasional pendidikan meskipun menambah jam pelajarannya. Hal ini menyesuaikan dengan PP Nomor 55 Tahun 2007 tentang Pendidikan Agama dan Keagamaan pasal 5 ayat (1) yang menyatakan bahwa Kurikulum pendidikan agama dilaksanakan sesuai Standar Nasional Pendidikan. 
Selain mengembangkan kurikulum sendiri, SMP IT Al Fahmi yang merupakan jaringan sekolah Islam terpadu (JSIT) juga memakai kurikulum Dinas Pendidikan. Pola pendidikan pada sekolah Islam terpadu umumnya menggunakan dua kurikulum, yaitu kurikulum Diknas dan kurikulum JSIT (jaringan sekolah Islam terpadu). Dengan mengolaborasikan dua kurikulum tersebut merupakan upaya dalam meningkatkan kualitas anak didik yang sesuai dengan tujuan pendidikan Islam sendiri (Ismail, 2018).

Penyusunan kurikulum pada SMP IT Al Fahmi dilakukan oleh yayasan bersama kepala sekolah dan guru yang mengacu pada standar mutu kekhasan sekolah Islam terpadu. Penyusunan ini juga mempertimbangkan aspek keseimbangan materi pembelajaran agama, umum, dan sains. Dan dibuat seefisien mungkin agar tujuan pembelajaran dan kompetensi peserta didik dapat tercapai. Dan tetap memperhatikan perkembangan dan tuntutan kebutuhan pendidikan masyarakat agar tetap relevan terhadap ilmu pengetahuan dan teknologi. Ibnu Khaldun mengungkapkan prinsip-prinsip yang melandasi penyusunan kurikulum, yaitu; prinsip al-Takamul (integritas), al-Tawazun (keseimbangan), alSyumul (menyeluruh), prinsip orientasi pada tuhan, al-Ittisal (kontinuitas), prinsip sinkronisasi, prinsip relevansi, efisiensi, dan efektivitas. (Standar Mutu SIT, 2010).

Kurikulum yang dikembangkan sebaiknya juga memperhatikan perkembangan dan kemampuan akademik peserta didik dalam memahami pembelajaran, serta memperhatikan kehidupan sosial masyarakat. Sudjana dalam Gunawan (2012:13) menjabarkan isi kurikulum yang dapat menentukan berhasilnya suatu tujuan, yaitu sebagai berikut: (1) Isi kurikulum harus sesuai tepat dan bermakna bagi perkembangan siswa atau peserta didik, artinya sejalan dengan tahap perkembangan anak (2) Isi kurikulum harus mencerminkan kenyataan sosial, artinya sesuai dengan tuntutan hidup nyata dalam masyarakat (3) Isi kurikulum dapat mencapai tujuan yang komprehensif, artinya mengandung aspek intelektual, moral, dan sosial secara seimbang (4) Isi kurikulum harus mengandung pengetahuan ilmiah yang tahan uji, artinya tidak cepat lapuk hanya karena perubahan tuntutan hidup sehari-hari (5) Isi kurikulum harus mengandung bahan pelajaran yang jelas, teori, prinsip, konsep yang terdapat di dalamnya bukan hanya sekedar informasi faktual (6) Isi kurikulum harus dapat menunjang tercapainya tujuan pendidikan yang nantinya dijabarkan dan dilaksanakan melalui proses pengajaran/pengalaman belajar anak didik.

Konstruksi dan pelaksanaan kurikulum pada SMP IT Al Fahmi memang sedikit berafiliasi dengan pendidikan agama, karena mengarahkan peserta didik untuk memiliki akhlak yang mulia, mempunyai sikap dan kepribadian yang islami. Hal ini menunjukkan bahwa kurikulum SMP IT Al Fahmi menyesuaikan dengan tujuan pendidikan Islam. Djamarah (2004:84) mengemukakan bahwa tujuan pendidikan Islam memiliki ciri-ciri yaitu: (1) Mengarahkan manusia agar menjadi khalifah Allah Swt. di muka bumi dengan sebaikbaiknya, yaitu melaksanakan tugas-tugas memakmurkan dan mengolah bumi sesuai dengan kehendak Allah Swt. (2) Mengarahkan manusia agar seluruh pelaksanaan tugas kekhalifahannya di muka dilaksanakan dalam rangka beribadah kepada Allah Swt. sehingga tugas tersebut terasa ringan dilaksanakan (3) Mengarahkan manusia agar berakhlak mulia, sehingga ia tidak menyalahgunakan fungsi kekhalifahannya (4) Membina dan mengarahkan potensi akal, jiwa dan jasmaninya, sehingga ia memiliki ilmu, akhlak dan keterampilan yang semua ini dapat digunakan guna mendukung tugas pengabdian dan kekhalifahannya (5) Mengarahkan manusia agar dapat mencapai kebahagiaan hidup di dunia dan di akhirat.

Proses pelaksanaan pendidikan agama pada SMP IT Al Fahmi juga memperhatikan faktor psikologi pemahaman keagamaan peserta didik. Artinya materi-materi yang diberikan masih merunut pada aspek kognitif dan psikomotorik meskipun juga sedikit menyentuh aspek afektif. Karena peserta didik pada jenjang SMP memasuki usia yang berada pada tahap awal keremajaan. Perkembangan keagamaan anak pada masa remaja awal menurut Abin Syamsuddin (Mahmud, 2010:360) memiliki ciriciri, yaitu; (1) sikap negatif disebabkan alam pikirannya yang kritis melihat realitas orang- 
orang beragama yang hipokrit (pura-pura), (2) pandangan ketuhanan menjadi kacau karena beragamnya aliran paham yang saling bertentangan, (3) penghayatan rohaniahnya cenderung skeptis, sehingga banyak yang enggan melaksanakan ritual yang selama ini dilakukan dengan penuh kepatuhan.

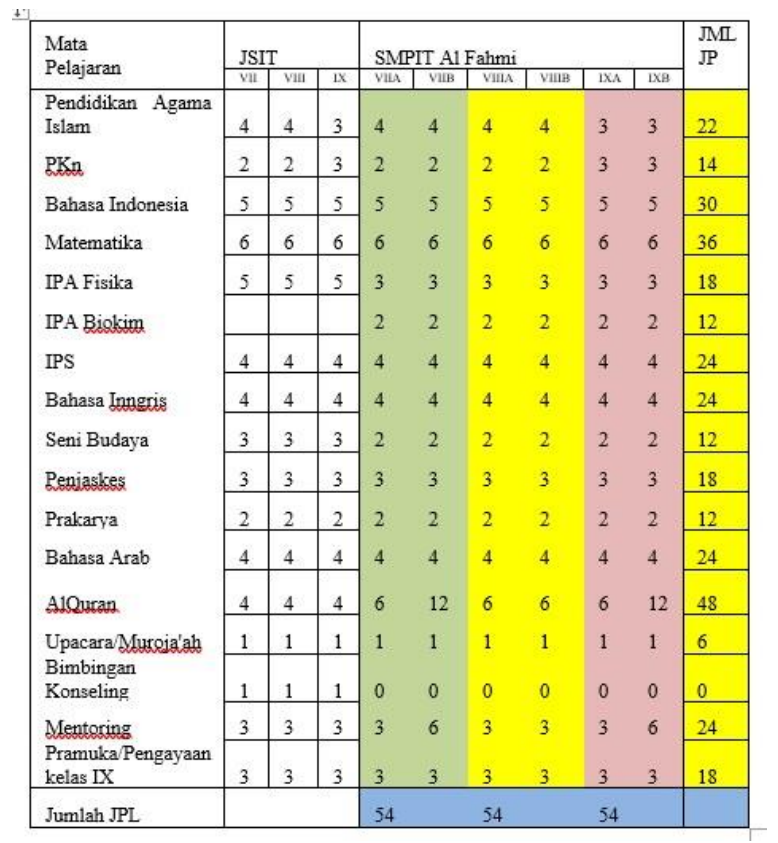

Struktur Kurikulum Kelas VII, VIII, IX

Dari gambaran struktur kurikulum SMP IT Al Fahmi, terlihat bahwa jumlah jam pelajaran selama satu minggu sebanyak 54 jam pelajaran. Lebih banyak jika dibandingkan dengan jumlah jam pelajaran pada Madrasah Tsanawiyah sebanyak 41 jam pelajaran (tidak termasuk pengembangan diri dua jam pelajaran).

Pendidikan agama Islam (PAI) pada SMP IT Al Fahmi merupakan satu bagian utuh mata pelajaran. Berbeda dengan Madrasah Tsanawiyah, pelajaran PAI bersifat parsial yang terdiri dari empat mata pelajaran (delapan jam pelajaran) yaitu; Al Quran Hadits, Akidah Akhlak, Fiqih, dan Sejarah Kebudayaan Islam. Meskipun begitu mata pelajaran PAI pada SMP IT Al Fahmi tetap memuat unsur-unsur Akidah Akhlak, Fiqih, dan Sejarah Kebudayaan Islam. Sedangkan pembelajaran Al Quran diampuh pada mata pelajaran tersendiri, dan jumlah jam pelajarannya sebanyak enam sampai 12 jam pelajaran. Untuk pelajaran bahasa Arab, jumlah jam pelajaran pada Madrasah Tsanawiyah sebanyak tiga jam pelajaran sedangkan di SMP IT Al Fahmi sebanyak empat jam pelajaran.

Penambahan jam pelajaran yang berhubungan dengan pendidikan agama terutama Al Quran dan bahasa Arab memang sangat memungkinkan karena mata pelajaran umum lainnya pada SMP IT Al Fahmi mengintegrasikan nilai-nilai agama Islam yang di dalamnya memuat ayat-ayat dari Al Quran. Sehingga peserta didik dituntut untuk memahami lebih banyak kandungan Al Quran. Begitu pun juga bahasa Arab yang memberikan porsi jam pelajaran agak lebih, karena memang merupakan salah satu kompetensi yang harus dicapai peserta didik yaitu mampu berbahasa Arab, dan juga merupakan kekhasan dan keunggulan dari SMP IT Al Fahmi. Penambahan jam pelajaran pendidikan agama ini juga sudah sejalan dengan Peraturan Pemerintah Nomor 55 Tahun 2007 tentang pendidikan Agama dan Keagamaan pasal 5 ayat (8) yang menyatakan bahwa satuan pendidikan dapat menambah muatan pendidikan agama sesuai kebutuhan.

Selain pembelajaran inti dari hari senin sampai hari Jumat, juga diadakan pengayaan pada hari Sabtu yang dituangkan dalam beberapa kelompok pembelajaran, yaitu diantaranya; kelas Olimpiade, kelas tahfidz Al Quran, kelas seni, dan kelas olahraga. Kelas Olimpiade diperuntukkan bagi peserta didik yang mempunyai kemampuan lebih pada mata pelajaran sains seperti matematika atau ilmu pengetahuan alam (IPA). Kelas tahfidz diperuntukkan bagi peserta didik yang memiliki kemampuan atau bakat menghafal Al Quran lebih dari dua juz (kompetensi yang diprasyaratkan pada SMP IT Al Fahmi). Kelas seni dan olahraga diperuntukkan untuk mengasah kemampuan peserta didik pada bidang seni, panahan, renang, dan silat. Program pembelajaran ini secara tidak langsung telah merujuk pada Peraturan Pemerintah Nomor 55 Tahun 2007 tentang pendidikan Agama dan Keagamaan pasal 5 ayat (6) Pendidikan agama menumbuhkan sikap kritis, inovatif, dan dinamis, sehingga menjadi pendorong peserta didik untuk memiliki kompetensi dalam bidang ilmu pengetahuan, teknologi, seni, dan/atau olahraga. 
Pengayaan untuk memenuhi kompetensi bahasa Arab dan bahasa Inggris, adalah dengan menerapkan hari bahasa Inggris (english day) pada hari Senin dan kamis dan pada hari jum'at diterapkan hari bahasa Arab (arabic day).

Program pembelajaran lainnya pada SMP IT Al Fahmi adalah kegiatan english camp, Quran camp, dan pramuka camp. Kegiatan ini dimaksudkan untuk pengayaan pembelajaran bahasa Inggris, bahasa Arab, dan kepemimpinan. Juga untuk penerapan pembelajaran dan implikasinya terhadap lingkungan alam sekitar. Selain itu juga untuk memberikan penyegaran rohani dan jasmani kepada peserta didik agar nantinya sekembali dari kegiatan tersebut dapat memulai pelajaran dengan perasaan tenang, nyaman, dan gembira. Program kegiatan pembelajaran ini juga sudah sejalan dengan Peraturan Pemerintah Nomor 55 Tahun 2007 tentang pendidikan Agama dan Keagamaan pasal 5 ayat (7) yang menyatakan bahwa pendidikan agama diselenggarakan secara interaktif, inspiratif, menyenangkan, menantang, mendorong kreativitas dan kemandirian, serta menumbuhkan motivasi untuk hidup sukses.

Implementasi pendidikan agama terkait dengan pelaksanaan tata tertib di SMP IT Al Fahmi adalah adanya sanksi yang melanggar peraturan tersebut, berupa tugas untuk menghafal beberapa ayat Al Quran atau hadis dan menunda waktu kepulangan peserta didik tersebut yang melanggar (jam pulang pukul 17.00 WITA dari waktu normal pukul 16.00 WITA). Tujuan sanksi tersebut, selain untuk menumbuhkan dan memperkuat sikap kedisiplinan peserta didik, juga secara tidak langsung menambah wawasan keagamaan (religious knowledge) peserta didik.

Wakil kepala sekolah (Bapak Abd. Ghofur) selain mengampuh mata pelajaran Taksin/Alquran, juga diberikan tugas untuk mengontrol dan mengawasi keseharian siswa di sekolah dalam menjalankan tata tertib sekolah yang telah ditetapkan. Seperti ketepatan waktu masuk sekolah, adab berkomunikasi, kerapian pakaian, kepatuhan mengerjakan tugas, ketaatan beribadah siswa, sampai kepada norma-norma sosial siswa di rumah. Terkait dengan normanorma sosial siswa di rumah, Bapak Abd.
Ghofur membangun komunikasi dengan orang tua siswa. Strategi dan cara yang dilakukan oleh Bapak Abd.Ghofur sangat efektif dalam membentuk sikap dan karakter kepribadian siswa ke arah yang lebih baik.

\section{Sistem Pembelajaran}

Sistem pembelajaran pada SMP IT Al Fahmi merujuk pada standar mutu dari JSIT, termasuk di dalamnya strategi, metode, dan pendekatan, serta langkah-langkah pembelajaran. Semuanya ini merupakan pendukung dalam proses pembelajaran tanpa mengabaikan aspek kognitif, afektif, dan psikomotorik agar tujuan pendidikan secara umum dapat tercapai. Pendidikan bertujuan untuk mengembangkan potensi peserta didik baik dari segi kognitif, psikomotorik dan afektif (Pertiwi, 2018). Dalam upaya mencapai tujuan yang telah ditetapkan, maka perlu diupayakan kesamaan bobot antara domain kognitif, afektif dan psikomotorik (Syahid, 2018)

Proses pembelajaran didasari pada rencana pelaksanaan pembelajaran (RPP). Di dalam RPP ini memuat kompetensi dasar mata pelajaran, indikator, dan acuan belajar. Indikator yang juga akan menjadi penilaian memuat aspek spiritual, sikap, pengetahuan, dan keterampilan. Sedangkan acuan belajar mengurai aspek-aspek pembelajaran yaitu langkah pembelajaran, kegiatan pembelajaran, skenario pembelajaran, metode dan pendekatan pembelajaran, dan media atau alat peraga yang digunakan.

Khusus langkah pembelajaran yang digunakan, merupakan salah satu ciri khas sekolah Islam terpadu karena mengurai kata 'TERPADU' menjadi tahapan awal melakukan pembelajaran, yaitu Telaah, Eksplorasi, Rumusan, Presentasikan, Aplikasikan, Duniawi, Ukhrowi. Pada unsur duniawi dan ukhrawi ini yang diletakkan nilai-nilai agama Islam pada pembelajaran. Maksud dari ini agar peserta didik memiliki pemahaman dan penghayatan pada agama Islam yang merunut pada kekhasan SMP IT Al Fahmi dan tujuan pendidikan agama Islam itu sendiri yang dikembangkan di sekolah, tidak hanya pada aspek kognitif saja. Mochtar Buchori mengemukakan bahwa kegagalan pendidikan agama yang disebabkan karena praktik pendidikannya hanya memperhatikan aspek 
kognitif semata dari pertumbuhan kesadaran nilai-nilai (agama), dan mengabaikan pembinaan aspek afektif dan konatif-volutif yakni kemauan dan tekad untuk mengamalkan nila-nilai ajaran agama (Sumarna, Asyafah, and Kosasih, 2017)

Muhaimin (Gunawan, 2012:202) mengemukakan beberapa hal yang perlu diperhatikan dalam pembelajaran pendidikan agama Islam yaitu; (1) pendidikan agama Islam sebagai usaha sadar, yakni kegiatan bimbingan, pengajaran atau latihan yang dilakukan secara terencana dan sadar atas tujuan yang hendak dicapai. (2) peserta didik yang hendak disiapkan untuk mencapai tujuan, dalam arti ada yang dibimbing, diajari atau dilatih dalam meningkatkan keyakinan, pemahaman, penghayatan, dan pengamalan terhadap ajaran Islam. (3) pendidik atau guru pendidikan agama Islam yang melakukan bimbingan, pengajaran dan atau latihan secara sadar terhadap peserta didiknya untuk mencapai tujuan pendidikan agama Islam. (4) kegiatan pembelajaran pendidikan agama Islam diarahkan untuk meningkatkan keyakinan, pemahaman, penghayatan dan pengamalan ajaran agama Islam dari peserta didik, di samping untuk membentuk kesalehan dan kualitas pribadi juga untuk membentuk kesalehan sosial.

\section{Integrasi Nilai Islam pada Mata Pelajaran SMP IT Al Fahmi}

Salah satu kekhasan sekolah Islam terpadu adalah pada langkah pembelajaran yang memuat aspek duniawi ukhrawi, sehingga memberikan implikasi integrasi nilai-nilai Islam pada mata pelajaran umum (selain mata pelajaran agama). Integrasi dalam Sistem pembelajaran adalah sistem pembelajaran yang mengintegrasikan semua sistem dan proses belajar mengajar dalam satu kerangka lengkap (Fakhruddin, Bahruddin, and Mujahidin, 2018) Contoh integrasi nilai-nilai Islam pada pelajaran pendidikan jasmani dan kesehatan terdapat Guru meminta murid melafalkan kembali Ayat yang sudah dilafalkan sebelumnya (al-Mutaffifin ayat 1). Pelajaran matematika Mengkaji Al-Quran surah Al-Baqarah : 60, Dan (ingatlah) ketika Musa memohon air untuk kaumnya, lalu Kami berfirman: "Pukullah batu itu dengan tongkatmu". Lalu memancarlah dari padanya dua belas mata air. Sungguh tiap-tiap suku telah mengetahui tempat minumnya (masing-masing). Makan dan minumlah rezeki(yang diberikan) Allah, dan janganlah kamu berkeliaran di muka bumi dengan berbuat kerusakan.

Pelajaran lain yang mengintegrasikan nilai-nilai Islam sebagai berikut:

Bahasa Indonesia, Materi; puisi

\begin{tabular}{|c|c|}
\hline $\begin{array}{l}\text { Memahami pentingnya } \\
\text { memiliki adab yang baik } \\
\text { dalam berbicara maupun } \\
\text { mendengar dalam kehidupan } \\
\text { sehari hari }\end{array}$ & $\begin{array}{l}\text { Menyampaikan kepada } \\
\text { peserta didik hendaknya kita } \\
\text { selalu memiliki adab yang } \\
\text { baik pada saat berbicara } \\
\text { maupun mendengar dalam } \\
\text { kehidupan sehari-hari } \\
\text { sebagaimana dicontohkan } \\
\text { oleh Rasulullah }\end{array}$ \\
\hline $\begin{array}{l}\text { Memotivasi pesdik } \\
\text { menerapkan dalam } \\
\text { kehidupan sehari hari adab- } \\
\text { adab tersebut sebagai nilai } \\
\text { ibadah melalui Hadist } \\
\text { Riwayat Muslim yang } \\
\text { artinya "kata-kata yang baik } \\
\text { itu adalah SEDEKAH" }\end{array}$ & $\begin{array}{l}\text { Memotivasi peserta didik } \\
\text { hendaknya selalu berinteraksi } \\
\text { sesama manusia dengan adab } \\
\text { yang baik, yang in shaa Allah } \\
\text { selain akan menjadi nilai } \\
\text { yang baik di dunia, juga akan } \\
\text { menjadi nilai ibadah dan } \\
\text { pahala. }\end{array}$ \\
\hline
\end{tabular}

Bahasa Inggris, Materi; The Chlothes We Wear

\begin{tabular}{|l|l|}
\hline $\begin{array}{l}\text { Siswa mempelajari pakaian- } \\
\text { pakaianyang sopan sesuai } \\
\text { dengan cuaca dan syariat } \\
\text { Islam }\end{array}$ & $\begin{array}{l}\text { Memperlihatkan contoh - } \\
\text { contoh pakaian dan yang } \\
\text { tidak baik kain yang } \\
\text { sekarang banyak di gunalkan } \\
\text { oleh masyarakat }\end{array}$ \\
\hline $\begin{array}{l}\text { Sebaiknya siswa tetap } \\
\text { menjaga pakaiannya } \\
\text { agaisesuai dengan ajaran } \\
\text { islam sebagai kepatuhan kita } \\
\text { terhapap ajaran Rasullullah } \\
\text { SAW }\end{array}$ & $\begin{array}{l}\text { Guru menjelaskan ayat Al- } \\
\text { quran yang menjelaskan } \\
\text { tentang kewajiban kita } \\
\text { menutup aurat QS: } \\
\text { AL_AHZAB : 59 }\end{array}$ \\
\hline
\end{tabular}

IPA Biologi, Materi; pertumbuhan dan perkembangan

\begin{tabular}{|c|c|}
\hline $\begin{array}{l}\text { Menanam bunga dan } \\
\text { merawatnya } \\
\text { Memberikan kepedulian pada } \\
\text { lingkungan( baik tumbuhan } \\
\text { dan hewan) }\end{array}$ & $\begin{array}{l}\text { Menyepakati tugas piket- } \\
\text { piket memelihara bunga ( } \\
\text { menyiram, membersihkan } \\
\text { dll.) }\end{array}$ \\
\hline $\begin{array}{l}\text { Program memelihara di } \\
\text { sekitar lingkungan sebagai } \\
\text { bentuk rasa syukur terhadap } \\
\text { ciptaan Allah SWT }\end{array}$ & $\begin{array}{l}\text { Membiasakan peduli } \\
\text { lingkungan } \\
\text { ( QS Al-Haaj ayat } 5 \text { dan Ayat } \\
\text { tentang rezeki. }\end{array}$ \\
\hline
\end{tabular}


IPA Fisika, Materi; Gaya dan Hukum Newton

\begin{tabular}{|l|l|}
\hline $\begin{array}{l}\text { Memberi pemahaman } \\
\text { kepada siswa tentang } \\
\text { pentingnya sikap tolong } \\
\text { menolong. }\end{array}$ & $\begin{array}{l}\text { Menjelaskan bahwa apabila kita } \\
\text { melakukan sesuatu bersama- } \\
\text { sama, maka akan lebih mudah } \\
\text { menyelesaikan pekerjaan } \\
\text { tersebut. }\end{array}$ \\
\hline $\begin{array}{l}\text { Menanamkan dalam diri } \\
\text { siswa bahwa Allah Maha } \\
\text { Adil. }\end{array}$ & $\begin{array}{l}\text { Interaksi sosial, bahwa balasan } \\
\text { dari kebaikan adalah kebaikan } \\
\text { pula (QS. Ar Rahman : 60). } \\
\text { Apabila kita membantu satu } \\
\text { kesulitan orang lain, maka Allah } \\
\text { akan membantu kesulitan kita di } \\
\text { dunia dan akhirat. }\end{array}$ \\
\hline
\end{tabular}

IPS Terpadu, Materi; Memahami permasalahan sosial berkaitan dengan pertumbuhan jumlah penduduk

\begin{tabular}{|c|c|}
\hline $\begin{array}{l}\text { Menjaga keanekaragaman } \\
\text { suku, etnis, budaya, bahasa } \\
\text { dan lingkungan alam } \\
\text { Saling memuliakan di } \\
\text { antara tetangga. }\end{array}$ & $\begin{array}{l}\text { Saling } \\
\text { menghormati/menghargai atas } \\
\text { segala perbedaan dalam } \\
\text { kehidupan bermasyarakat, } \\
\text { berbangsa dan bernegara. } \\
\text { Barang siapa membantu } \\
\text { saudaranya yang dalam } \\
\text { kesusahan maka Allah akan } \\
\text { memberikan jalan keluar \& } \\
\text { Reski yang tidak disangkanya. } \\
\text { Al hujurat } \\
\text { Telah Nampak kerusakan di atas } \\
\text { bumi ini, laut dan darat, udara } \\
\text { akibat ulah manusia itu sendiri. } \\
\text { Maka Allah menurunkan bala } \\
\text { bencana akibat perbuatan } \\
\text { manusia, agar manusia kembali } \\
\text { kepada jalan Tuhan-Nya }\end{array}$ \\
\hline
\end{tabular}

Matematika, Materi; Faktorisasi Bentuk Aljabar

\begin{tabular}{|c|c|}
\hline $\begin{array}{l}\text { Mempelajari manfaat } \\
\text { penggunaan operasi } \\
\text { aljabar dalam kehidupan } \\
\text { sehari-hari }\end{array}$ & $\begin{array}{l}\text { Guru melakukan tanya jawab } \\
\text { dengan siswa mengenai manfaat } \\
\text { penggunaan operasi aljabar dalam } \\
\text { kehidupan sehari-hari dan } \\
\text { menyajikan gambar-gambar } \\
\text { penggunaan operasi aljabar dalam } \\
\text { kehidupan sehari-hari. }\end{array}$ \\
\hline $\begin{array}{l}\text { Mengkaji surah Al- } \\
\text { Baqarah : } 245\end{array}$ & $\begin{array}{l}\text { Guru bersama-sama siswa } \\
\text { mengkaji surah al-baqarah : } 245 \\
\text { yang artinya : Siapakah yang mau } \\
\text { memberi pinjaman kepada Allah, } \\
\text { pinjaman yang baik (menafkahkan } \\
\text { hartanya di jalan Allah), maka } \\
\text { Allah akan melipatgandakan } \\
\text { pembayaran kepadanya dengan } \\
\text { lipat ganda yang banyak. Dan } \\
\text { Allah menyempitkan dan } \\
\text { melapangkan (rezeki) dan kepada- } \\
\text { Nya-lah kamu dikembalikan }\end{array}$ \\
\hline
\end{tabular}

Prakarya, Materi; benda berharga dalam keluarga

\begin{tabular}{|l|l|}
\hline $\begin{array}{l}\text { Menjaga kebersihan dan } \\
\text { kerapian } \\
\text { pribadi miliknya dan benda- } \\
\text { benda yang ada di dalam } \\
\text { kelas }\end{array}$ & $\begin{array}{l}\text { Santri membiasakan diri } \\
\text { untuk menjaga kebersihan } \\
\text { dan kerapian benda-benda } \\
\text { miliknya dan benda-benda } \\
\text { yang ada di dalam kelas }\end{array}$ \\
\hline $\begin{array}{l}\text { Allah mencintai hambanya } \\
\text { yang bekerja selalu rapi dan } \\
\text { bertanggung jawab }\end{array}$ & $\begin{array}{l}\text { Hadits : " Sesungguhnya } \\
\text { Allah mencintai seseorang di } \\
\text { antara kamu yang apabila } \\
\text { bekerja selalu rapi ( HR, } \\
\text { Baihaqi)" }\end{array}$ \\
\hline
\end{tabular}

\section{PENUTUP}

Kurikulum SMP IT Al Fahmi Palu, menyesuaikan dengan ciri khas sekolah Islam terpadu yaitu mengintegrasikan nilai-nilai atau ilmu Islam baik yang bersifat Qualiyah maupun Kauniyah dalam suatu kerangka atau bangunan kurikulum. Salah satu tujuannya adalah peserta didik memiliki kepribadian salimul Aqidah (akidah yang bersih). Pelaksanaan pendidikan agama Islam (PAI) selain bersifat monolitik atau berdiri sendiri juga terintegrasi atau mengilhami proses pelaksanaan pendidikan. Artinya kegiatan-kegiatan yang ada di SMP IT Al Fahmi ataupun proses belajar mengajar dapat memberikan pengetahuan yang berhubungan dengan agama Islam kepada peserta didik.

Pengembangan PAI pada kurikulum SMP IT Al Fahmi dapat dilihat mulai dari penambahan jam pelajaran pada mata pelajaran pendidikan agama Islam, Al Quran, dan bahasa Arab. Integrasi nilai-nilai Islam pada mata pelajaran umum, pelajaran ekstrakurikuler memanah, renang, dan silat yang setidaknya telah mengikuti sunah Nabi tentang seni dan keterampilan diri yang sebaiknya dimiliki oleh umat Islam. Kelas tahfidz bagi peserta didik yang memiliki bakat untuk meningkatkan hafalan Al Quran. Adanya kegiatan Quran camp. Sanksi hafalan beberapa ayat Al Quran bagi peserta didik yang melanggar tata tertib sekolah.

Adanya enkulturasi nilai-nilai agama Islam pada sekolah Islam terpadu karena begitu kentalnya adab-adab keislaman pada interaksi sosial di sekolah. Mulai dari pengintegrasian nilai-nilai Islam pada mata pelajaran umum, tata cara berpakaian, penghormatan kepada guru dan sesama peserta didik, ketaatan peribadatan, adab 
berbahasa, sampai kepada pemberian sanksi yang semuanya diilhami nilai-nilai keislaman. Olehnya Kementerian Agama dan Kementerian Pendidikan Nasional perlu membangun komunikasi atau kerja sama untuk mengembangkan sekolah Islam terpadu. Komunikasi atau kerja sama yang dimaksud adalah penyelarasan bantuan pengembangan pendidikan. Kementerian Agama bertanggungjawab kepada pengembangan pendidikan Agama Islam dan pembinaan guruguru dalam mengembangkan kompetensi yang berhubungan dengan agama Islam, dan juga sarana dan prasarana sekolah yang berhubungan dengan kegiatan keagamaan. Kementerian Pendidikan bertanggungjawab pada pengembangan pelajaran umum, pengembangan kompetensi guru-guru mata pelajaran umum, dan sarana prasarana sekolah lainnya.

Kompetensi guru pada SMP IT Al Fahmi belum sepenuhnya memiliki uji kelayakan profesi sebagai guru. Guru mata pelajaran umum sebaiknya memiliki kompetensi mata pelajaran yang diampuh dan kompetensi sebagai guru agama, karena juga memberikan pengetahuan agama kepada peserta didik. Tetapi meskipun begitu, semangat dari para guru-guru patut dihargai dalam mengabdi dan memberikan yang terbaik bagi para siswa SMP IT Al Fahmi, baik dalam hal pendidikan umum, pendidikan agama, sampai kepada pembentukan pribadi siswa yang berakhlak mulia, berkarakter baik, serta berdedikasi untuk berprestasi yang terbaik.

Perlu kiranya pemerintah memberikan dorongan dan pembinaan kepada guru-guru SIT untuk meningkatkan kompetensinya. Pembinaan tersebut dapat berupa pendidikan dan latihan, bantuan pendidikan untuk melanjutkan sekolah dalam bidang agama Islam bagi guru-guru mata pelajaran umum, atau memberikan kesempatan kepada guru untuk mengabdi sebagai aparatur negara. Tapi tentunya semua ini akan maksimal bila dibarengi dengan kebijakan atau regulasi yang berhubungan dengan kompetensi guru SIT.

Standar kompetensi lulusan yang menjadi salah satu keunggulan SMP IT Al Fahmi adalah peserta didik dapat menghafal Alquran minimal 2 juz, mampu berbahasa Inggris, serta mampu berkomunikasi dengan bahasa Arab. Selain itu, peserta didik kelas IX atau sebelum lulus ujian akhir harus mengikuti kegiatan praktik lapangan, yaitu terjun di tengahtengah masyarakat untuk mengabdikan ilmunya seperti mengajar di TPA-TPA/TPQ. Program pembelajaran lainnya adalah adanya english day, yaitu setiap hari kamis semua warga sekolah wajib berbahasa Inggris, mulai dari kepala sekolah, guru, tenaga kependidikan sampai kepada petugas-petugas kebersihan.

\section{DAFTAR PUSTAKA}

Al-Quran dan Terjemahannya. 1989. Departemen Agama. Toha Putera.

Aziz, Helmi. 2018. "Kurikulum Integratif Berbasis Nilai-Nilai Islam ( Penelitian Di SMP IT Fithrah Insani Kabupaten Bandung Barat )." Tadris 13 (1): 94-111.

Budi Hadi. Makalah. Manajemen Pendidikan Islam Terpadu Dalam Membentuk Siswa Berakhlak Mulia Studi Kasus di SDIT Muhammadiyah Al-Kautsar Gumpang Kartasura Sukoharjo Tahun 2012-2013. Program Pascasarjana Universitas Muhammadiyah Surakarta Tahun 2013.

Darmin, Sudarwan. 2006. Agenda Pembaruan Sistem Pendidikan. Pustaka Pelajar. Yogyakarta.

Djamarah, Syaiful Bahri. 2004. Pola Komunikasi Orang Tua dan Anak Dalam Keluarga; Sebuah Perspektif Pendidikan Islam. PT Rineka Cipta. Jakarta.

Euis Sumaiyah. Makalah. Implementasi Konsep Pendidikan Islam Terpadu Di SMP Islam Terpadu PAPB Pedurungan Semarang. Fakultas Tarbiyah Institut Agama Islam Negeri Walisongo Semarang 2010.

Fakhruddin Udi, Ending Bahruddin, and Endin Mujahidin. 2018. "Konsep Integrasi Dalam Sistem Pembelajaran Mata Pelajaran Umum Di Pesantren." Ta'dibuna 7 (2): 214-32.

Gunawan, Heri. 2012. Kurikulum dan Pembelajaran Pendidikan Agama Islam. Alfabeta. Bandung. 
Iqbal, Abu Muhammad.2015. Pemikiran Pendidikan Islam; Gagasan-Gagasan Besar Para Ilmuwan Islam. Pustaka Pelajar. Yogyakarta.

Ismail, Fajri. 2018. "Pelaksanaan Kurikulum JSIT (Jaringan Sekolah Islam Terpadu) Di Sekolah Dasar Islam Terpadu Al-Furqon Palembang." Muaddib: Studi Kependidikan Dan Keislaman 08 (01): 14-33.

Mahmud. 2010. Psikologi Pendidikan. Pustaka Setia. Bandung.

Peraturan Pemerintah Republik Indonesia Nomor 55 Tahun 2007 tentang Pendidikan Agama dan Pendidikan Keagamaan.

Pertiwi, Putri Lingga. 2018. "Internalisasi NilaiNilai Toleransi Dalam Sistem Boarding School Di Sekolah Menengah Pertama Islam Terpadu (SMP IT) Al Bashiroh Turen-Malang” 1 (1): 57-66.

Soemanto. 2014. Edukasi. Jurnal Penelitian Pendidikan Agama dan Keagamaan. Volume 12. Nomor 2. Hal. 247-260.
Sumarna, Andri Ramdani, Abas Asyafah, and Kosasih. 2017. "PENGELOLAAN Pendidikan Agama Islam Di Islamic Full Day School Smp Salman Al-Farisi." Tarbawy: Indonesian Journal of Islamic Education 4 (2): 179-90.

Suprapto. 2014. Edukasi. Jurnal Penelitian Pendidikan Agama dan Keagamaan. Volume 12. Nomor 1. Hal. 27-41.

Syahid, Nur. 2018. "Pengembangan Kurikulum Pendidikan Di Lembaga Pesantren Al Khoziny Buduran Sidoarjo." Qudwatuna: Jurnal Pendidikan Islam I (2): 132-66.

Suyatno. Makalah Penelitian. Sekolah Islam Terpadu Dalam Peta Sistem Pendidikan Nasional. Prodi PGSD Universitas Ahmad Dahlan Yogyakarta.

Tim Penyusun Jaringan Sekolah Islam Terpadu Indonesia. 2010. Standar Mutu Sekolah Islam Terpadu. Jaringan Sekolah Islam Terpadu. Jakarta.

Tim Penulis Jaringan Sekolah Islam Terpadu Indonesia. 2014. Standar Mutu Kekhasan Sekolah Islam Terpadu. Jaringan Sekolah Islam Terpadu. Jakarta. 
134 | Jurnal “Al-Qalam” Volume 25 Nomor 1 Juni 2019 